\title{
Application and Prospects of Molecular Imaging
}

\author{
Guyrack Choi*, Sangbock Lee** \\ The Korean Society of Radiology Education Institute*, Dept. of Radiology, Nambu University ${ }^{* *}$
}

\section{분자영상의 적용분야 및 전망}

\author{
최규락*, 이상복** \\ 한국방사선학회교육원*, 남부대학교 방사선학과**
}

\begin{abstract}
In this paper, we study to classify molecular imaging and applications to predict future. Molecular imaging in vivo at the cellular level and the molecular level changes taking place to be imaged, that is molecular cell biology and imaging technology combined with the development of the new field. Molecular imaging is used fluorescence, bioluminescence, SPECT, PET, MRI, Ultrasound and other imaging technologies. That is applied to monitoring of gene therapy, cell tracking and monitoring of cell therapy, antibody imaging, drug development, molecular interaction picture, the near-infrared fluorescence imaging of cancer using fluorescence, bacteria using tumor-targeting imaging, therapeutic early assessment, prediction and therapy.

The future of molecular imaging would be developed through fused interdisciplinary research and mutual cooperation, which molecular cell biology, genetics, chemistry, physics, computer science, biomedical engineering, nuclear medicine, radiology, clinical medicine, etc. The advent of molecular imaging will be possible to early diagnosis and personalized treatment of disease in the future.
\end{abstract}

Key words: Optical Imaging, Nuclear Medicine Imaging, MRI, Molecular Imaging

\section{요 약}

본 논문에서는 분자영상을 분류하고 적용 분야와 미래를 예측해 보고자 하였다. 분자영상은 생체 내에서 분자 수준과 세포수준에서 일어나는 변화를 영상화하는 것으로써 분자세포생물학과 첨단영상기술이 발전하여 접목된 새로운 분야이다. 분자영상은 형광, 생물발광, SPECT, PET, MRI, Ultrasound 등의 영상 기법들을 이용하여 유전자 치료 모니터링, 세포추적, 세포 치료 모니터링, 항체영상, 약제 개발, 분자 상호작용 영상, 근적외선 형광 물질을 이 용한 암 형광 영상, Bacteria 를 이용한 종양 표적 영상, 치료효과 조기 평가, 치료 효과 예측 등에 적용되고 있다.

분자 영상의 미래는 분자세포 생물학, 유전학, 화학, 약학, 물리학, 전산학, 의공학, 핵의학, 영상의학, 임상의학 등 여러 학문 분야가 융합되어 상호협조와 공동연구를 통하여 발전해 나갈 것이다. 분자영상의 태동으로 미래의 의료의 모습은 질병의 조기진단과 개인 맞춤형 치료가 가능하게 될 것이다. 


\section{I. 서 론}

영상의학은 의료기술의 발전으로 정확한 질병의 진 단과 편리하게 영상을 획득할 수 있는 다양한 장비의 개발로 인하여 빠르게 발전하고 있다. 영상의학은 주 로 해부학적 형태의 변화와 일부 핵의학영상이나 자 기공명영상에서 기능적 정보를 영상화하고 이를 바탕 으로 질병의 진단에 이용하고 있다. 최근에 영상의학 은 나노기술과 결합된 분자영상으로 발전하고 있다. 분자영상(Molecular Imaging)은 세포 내에서 일어나는 여러 분자수준의 변화를 영상화하는 기법으로 첨단 영상기술과 분자세포생물학이 접목된 분야로서 의학, 유전학, 분자생물학, 세포학, 화학, 약학, 물리학, 의용 생체공학, 방사선학, 핵의학 등의 융합을 통하여 최근 에 급속히 발전하는 분야로서 SPECT(single photon emission computed tomography), PET(positron emission tomography), $\mathrm{MRI}$ (magnetic resonance imaging), 초음파영 상(ultrasonography), 형광(Fluorescence), 생물발광 (bioluminescence)등의 영상기술과 장비를 이용하여 암 의 조기진단, 새로운 의약품의 개발, 유전자치료, 줄기 세포 연구 및 치료, 질병치료 예후예측 등에 활용되고 있다 ${ }^{[1]}$. 분자영상은 생체조직을 손상시키지 않고 반복 적으로 영상화할 수 있는 기법으로서 세포수준의 기 초연구를 임상에 쓰일 수 있게 하는 중개연구 (translation research)의 중요한 부분이다. 분자영상을 이 용한 중개연구가 중요한 이유는 영상획득의 대상이 살아있는 상태에서 세포 또는 분자수준에서 일어나는 현상들을 영상을 통하여 직적 확인할 수 있게 하며, 확인된 현상들을 정량화하여 분석할 수 있도록 해주 기 때문에 주목을 받고 있다 ${ }^{[2]}$.

분자영상의 종류는 생체에서 생성되는 가시광선, 근적외선 영역의 빛을 영상으로 이용하는 광학영상 (optical imaging), 핵의학에 이용되는 방출단층영상 (emission tomography), 자기장 속에 놓여있는 원자핵에 서 발생하는 자기공명신호를 수신하여 영상화하는 $\mathrm{MRI}$, 컴퓨터단층촬영(computed tomography), 마이크로
버블을 이용하는 초음파영상(ultrasonography) 등이 있 다 ${ }^{[3]}$.

분자영상기법은 유전자의 활동, 단백질의 활성화 및 상호작용, 세포나 수용체의 분포 등 시험관이나 병 리학적 또는 조직학적인 관찰만이 가능했던 분자나 세포수준의 현상을 생체 내에서 실시간으로 영상화하 고자 하는 노력의 산물이다 ${ }^{[4]}$. 이렇게 분자영상 기법 으로 영상화 한다면 질병을 조기에 진단하여 치료의 효율을 높일 수 있게 될 것이며 질병의 근본적인 원인 의 규명도 가능하게 될 것이다. 또한 치료 중에 치료 의 효과를 조기에 판정함으로써 환자 개개인의 맞춤 치료가 가능하게 된다 ${ }^{[5]}$.

분자영상은 급속도로 발전하여 미래 의학발전을 주 도할 것으로 생각된다. 현재의 시점에서 보아도 분자 영상은 영상진단기술의 최첨단의 분야이며 넓은 분야 의 융합기술을 바탕으로 각종 전용 프로브를 이용해 체내 각 조직을 영상화하고 있다. 최근 미국과 유럽에 서는 침체된 경기로 인하여 분자영상 시장의 성장속 도가 하락하고 있지만 학술기관과 관련기업체의 개발 동향에 대한 관심은 증폭되어 최소 침습성의 더 높은 진단기술과 더 전문성이 높은 프로브 수요가 앞으로 도 분자영상 기술개발을 촉진할 것으로 사료된닽].

본 논문에서는 분자영상의 종류와 분자영상의 적용 분야를 살펴보고 분자영상 미래를 예측해 보고자 한다.

\section{II. 분자영상의 종류}

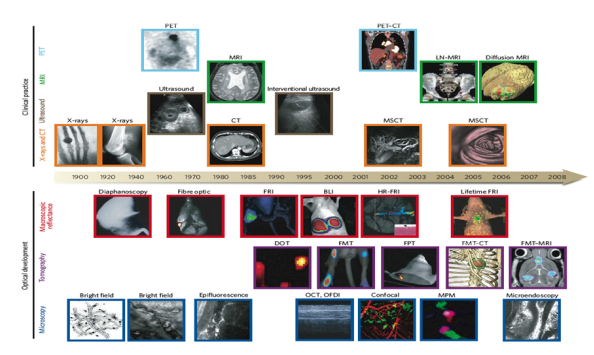

Fig. 1. Range of medical imaging. 
Table 1. Overview of imaging systems

\begin{tabular}{|c|c|c|c|c|c|c|c|c|c|c|}
\hline Technique & $\begin{array}{l}\text { Resolut } \\
\text { ion* }\end{array}$ & Depth & Time $†$ & $\begin{array}{l}\text { Quant } \\
\text { itati } \\
\text { ve } \ddagger\end{array}$ & $\begin{array}{c}\text { Multi } \\
- \\
\text { chann } \\
\text { el }\end{array}$ & Imaging agents & Target & $\begin{array}{c}\cos { }^{*} \\
\S\end{array}$ & $\begin{array}{l}\text { Main small- } \\
\text { animal use }\end{array}$ & $\begin{array}{l}\text { Clinical } \\
\text { use }\end{array}$ \\
\hline MRI & $\begin{array}{c}10 \sim 100 \\
\mu \mathrm{m}\end{array}$ & $\begin{array}{l}\text { No } \\
\text { I imit }\end{array}$ & $\begin{array}{l}\text { Minutes } \\
\text { to hours }\end{array}$ & Yes & No & $\begin{array}{l}\text { Paranagbetuc } \\
\text { chelates, } \\
\text { magnetic } \\
\text { par tuckes }\end{array}$ & $\begin{array}{l}\text { Anatomical, } \\
\text { physiological, } \\
\text { molecular }\end{array}$ & $\$ \$$ & $\begin{array}{l}\text { Versatile imaging } \\
\text { modal ity with high soft- } \\
\text { tissue contrast }\end{array}$ & Yes \\
\hline CT & $50 \mu \mathrm{m}$ & $\begin{array}{c}\text { No } \\
\text { I imit }\end{array}$ & Minutes & Yes & № & $\begin{array}{l}\text { Iodinated } \\
\text { molecules }\end{array}$ & $\begin{array}{l}\text { Anatomical, } \\
\text { physiological }\end{array}$ & $\$ \$$ & Imgaing lungs and bone & Yes \\
\hline UI trasound & $50 \mu \mathrm{m}$ & $\mathrm{cm}$ & $\begin{array}{l}\text { Seconds } \\
\text { to } \\
\text { minutes }\end{array}$ & Yes & № & Microbubbles & $\begin{array}{l}\text { Anatomical, } \\
\text { physiological }\end{array}$ & $\$ \$$ & $\begin{array}{c}\text { Vascular and } \\
\text { Interventional } \\
\text { imaging } \| \\
\end{array}$ & Yes \\
\hline PET & $1 \sim 2 \mathrm{~mm}$ & $\begin{array}{l}\text { No } \\
\text { I imit }\end{array}$ & $\begin{array}{l}\text { Minutes } \\
\text { to hours }\end{array}$ & Yes & No & $\begin{array}{c}\text { 18F-, 64Qu-or } \\
11 \mathrm{C}-\text { Iavel led } \\
\text { compounds }\end{array}$ & $\begin{array}{l}\text { Physiological, } \\
\text { molecular }\end{array}$ & $\$ \$$ & $\begin{array}{l}\text { Versatile imaging modal ity } \\
\text { with many tracers }\end{array}$ & Yes \\
\hline SPECT & $1 \sim 2 \mathrm{~mm}$ & $\begin{array}{l}\text { No } \\
\text { I imit }\end{array}$ & $\begin{array}{l}\text { Minutes } \\
\text { to hours }\end{array}$ & Yes & No & $\begin{array}{c}99 m T c-0 r \\
118 \text { In-label led } \\
\text { compounds }\end{array}$ & $\begin{array}{l}\text { Physiological, } \\
\text { molecular }\end{array}$ & $\$ \$$ & $\begin{array}{l}\text { Imaging lavel led } \\
\text { ant ibodies, } \\
\text { proteins and peptides }\end{array}$ & Yes \\
\hline $\begin{array}{l}\text { Fluorescence } \\
\text { reflectance } \\
\text { imaging }\end{array}$ & $2 \sim 3 m m$ & $<1 \mathrm{~cm}$ & $\begin{array}{l}\text { Seconds } \\
\text { to } \\
\text { minutes }\end{array}$ & No & Yes & $\begin{array}{l}\text { Photoproteins, } \\
\text { fluorochromes }\end{array}$ & $\begin{array}{l}\text { Physiological, } \\
\text { molecular }\end{array}$ & $\$$ & $\begin{array}{c}\text { Rapid screening of } \\
\text { molecular } \\
\text { events in surface-based } \\
\text { disease }\end{array}$ & Yes \\
\hline FMT & $1 \mathrm{~mm}$ & $<10 \mathrm{~cm}$ & $\begin{array}{l}\text { Minutes } \\
\text { to hours }\end{array}$ & Yes & Yes & $\begin{array}{l}\text { Near-infrared } \\
\text { fluorochromes }\end{array}$ & $\begin{array}{c}\text { Physiological, } \\
\text { molecular }\end{array}$ & $\$ \$$ & $\begin{array}{l}\text { Quant itat ive imaging of } \\
\text { fluorochrome reporters }\end{array}$ & $\begin{array}{c}\text { In } \\
\text { development }\end{array}$ \\
\hline $\begin{array}{c}\text { Bioluminesce } \\
\text { nce imaging }\end{array}$ & $\begin{array}{c}\text { Several } \\
\mathrm{mm}\end{array}$ & $\mathrm{cm}$ & Minutes & No & Yes & Luciferins & Molecular & $\$ \$$ & $\begin{array}{l}\text { Gene expression, cell and } \\
\text { bacter ium tracking }\end{array}$ & Yes \\
\hline $\begin{array}{l}\text { Intravital } \\
\text { microscopy } 9\end{array}$ & $1 \mu \mathrm{m}$ & $\begin{array}{c}<400 \sim \\
800 \mu \\
m\end{array}$ & $\begin{array}{l}\text { Seconds } \\
\text { to } \\
\text { hours }\end{array}$ & No & Yes & $\begin{array}{l}\text { Photoproteins, } \\
\text { fluorochromes }\end{array}$ & $\begin{array}{l}\text { Anatomical, } \\
\text { physiological, } \\
\text { molecular }\end{array}$ & $\$ \$$ & $\begin{array}{l}\text { All of the above at higher } \\
\text { resolutions but I imited } \\
\text { depths and coverage }\end{array}$ & $\begin{array}{c}\text { In } \\
\text { development }\end{array}$ \\
\hline \multicolumn{11}{|c|}{ 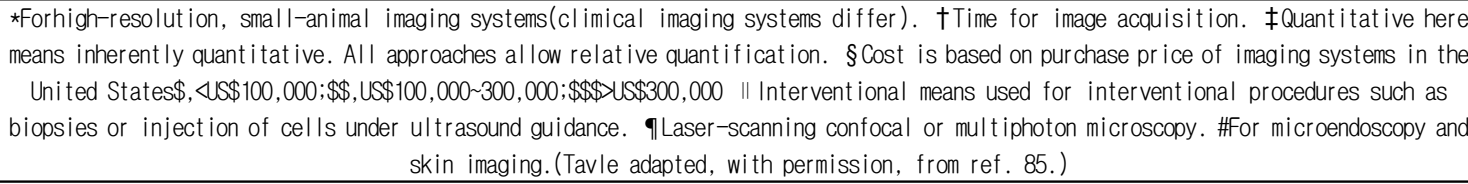 } \\
\hline
\end{tabular}

\section{1. 광학영상}

광학영상(optical imaging)은 가시광선영역과 적외선 영역의 파장대 광자가 나타내는 기술을 사용해서 생 물학적 영상을 볼 수 있는 기법이다. 광학영상은 크게 두 가지인 생물발광영상(bioluminescence imaging)과 형 광영상(fluorescence imaging)으로 나눌 수 있다 ${ }^{[7]}$.

광학영상에 있어서 가장 중요한 문제점은 어떻게 신체로부터 나오는 빛을 감지하여 영상화하느냐 하는 문제이다. 이 부분에 있어서, 가시광선과 같이 매우 낮 은 정도의 빛을 감지할 수 있는 검출기들이 개발되어 배양 중인 세포나 투명한 생명체가 아닌 살아있는 동 물에서 이러한 영상이 가능해지고 있다. 최근 개발된 전하결합 소자(CCD: charged coupled device) 검출기는 실리콘 칩 표면이 여러 개의 광 민감성 화소로 나뉘어
져 있다. 이러한 silicon-based detector는 가시광선부터 근 적외선 영역의 빛을 감지하는데 그 예민도가 매우 뛰어나서 400-1000 nm 대의 파장과, 약 2-3 eV의 에너 지를 가지고 있는 광자가 $\mathrm{CCD}$ 화소에 부딪히면 광자 가 전자로 변환된다. $\mathrm{CCD}$ 는 반도체로 구성되어 있어 변환된 전자를 증폭시키기가 용의하다. 이제까지의 $\mathrm{CCD}$ 는 $\mathrm{CCD}$ chip의 실리콘 격자에서 발생하는 열 에 너지에 의해 전자가 긇임없이 배출되는 잡음 때문에 낮은 예민도를 보였다. 발생하는 열로 인한 잡음은 $\mathrm{CCD}$ 칩을 냉각하면 되는데 $\mathrm{CCD}$ 칩은 매 $20^{\circ} \mathrm{C}$ 온도 감소마다 10 배의 잡음이 감소하므로, 최근 $\mathrm{CCD}$ 를 $-120 \sim-150^{\circ} \mathrm{C}$ 까지 냉각시켜 예민도를 획기적으로 개선 시켰다.

$\mathrm{CCD}$ 카메라 영상은 최근의 발전에도 불구하고 여 전히 몇 가지 주요 결점을 가지고 있다. 첫째, 불투명 
한 동물에서 빛의 투과 효율이 낮아 조직의 유형이나 조직에서의 산란에 크게 영향을 받는다. 즉, 피부나 근 육과 같은 조직은 투과효율이 높아 파장에 비례하여 투과력이 개선될 수 있지만, 간과 비장같이 혈류가 많 은 기관은 헤모글로빈이나 산화 헤모글로빈에서의 광 흡수 작용에 의해 빛의 투과율이 매우 낮다. 둘째, 냉 각 $\mathrm{CCD}$ 카메라에서는 2차원적인 영상이 생성되어 영 상 신호의 깊이에 대한 정보가 결핍되어 있다. 이러한 결점을 보완하기 위해 회전 $\mathrm{CCD}$ 카메라가 개발되고 있거나, 단일 $\mathrm{CCD}$ 카메라로 여러 각도에서 이미지를 획득하여 체적 영상을 얻는 방법이 고안되고 있다. 또 한 CCD 카메라 대신에 광전자 증배관(photomultiplier tube)를 사용하는 방법도 고안되고 있다 ${ }^{[8]}$.

\section{1. 생물발광영상(bioluminescence imaging)}

생물발광영상은 화학적으로 생체 내에서 빛을 만들 어 방출하고 방출되는 빛을 이용하여 영상화하는 방 법으로 대표적인 예로는 반딧불이(firefly)의 루시페린 (luciferin)이라는 발광물질이 루시페라제(luciferase)라는 효소에 의해 산화되면서 빛을 내게 되는 경우이다. 연 구자는 루시페라제를 추적관찰하기 원하는 세포나 조 직 또는 유전자에 주입(transfection)시키고 효소작용에 필요한 기질인 루시페린을 투여하는 방법으로 영상을 만든다. Fig. 1은 Nude 생쥐의 복부에 심은 종양 세포 에 HSV amplicon을 이용하여 Renilla 루시페라제 유전 자를 삽입시킨 후 3 일 뒤 루시페린을 정맥주사 하였을 때 발산하는 빛을 10 분간 포착한 영상이다. 빛이 발산 되는 위치마다 그 양에 따라 영상처리 프로그램으로 무지개색을 코딩하였다. 좌측 생주의 종양에 비해 루 시페라제 유전자가 5배 많이 주입된 우측 생쥐의 종양 이 루시페라제 영상에서 빛을 약 5 배 많이 방출함을 알 수 있다, 반면에 유전자가 삽입되지 않은 종양과 생체의 다른 부위에는 전혀 노이즈가 없음을 알 수 있 다.

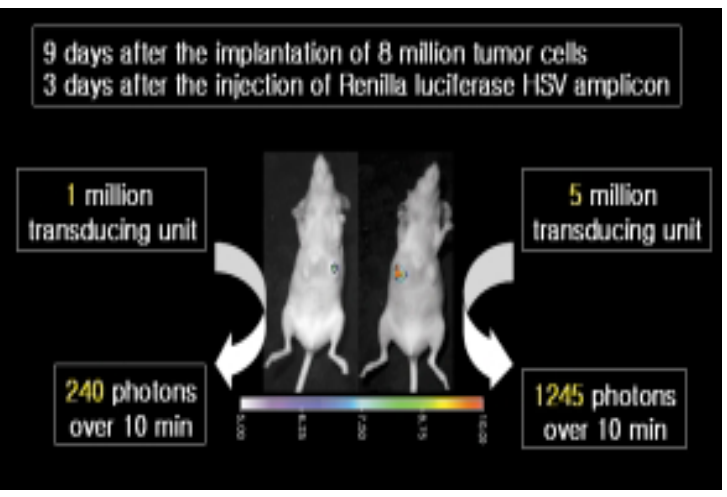

Fig. 2. Molecular imaging using light-emitting materials.

형광영상에 비해생물발광영상의 장점은 배경 영상 노이즈(background noise)가 거의 없고, 생체 내에 더 깊 은 곳( $2 \mathrm{~cm}$ 이상)에서 나오는 빛을 감지할 수 있으며, 생쥐와 같은 소동물(small animals)에서 수초에서 수분 의 짧은 시간 내에 한번에 5 6마리 이상의 영상을 획 득할 수 있다는 것 등이 장점이다 ${ }^{[9]}$. 특히 생물발광영 상은 반정량적(semi-quantitative)이어서(Fig. 2), 종양 치 료의 효과를 정략적으로 분석하거나 ${ }^{[10]}$ 줄기세포(stem cell) 치료 후 이식편의 생존율(graft Survival)을 분석 ${ }^{[11]}$ 하는 등의 실험에 유용하게 사용될 수 있다. 세포에 삽입된 루시페라제가 루시페린을 만나서 방출하는 빛 의 양(photon counts)이 세포의 수에 비례한다 ${ }^{[12]}$.

형광영상의 큰 장점이 다양한 스펙트럼의 형광물질 들을 이용해 동시에 여러 가지 생물학적 현상을 영상 화(multichannel imaging)할 수 있다는 점이지만 ${ }^{[9]}$ 생물 발광영상에서도 반딧불이(firefly) 루시페라제는 반딧불 이 루시페린에 의해서만, Renilla 루시페라제는 Renilla 루시페린에 의해서만 빛을 낸다.

Shah 등은 ${ }^{[13]}$ 신경교증이 Renilla 루시페라제를 발현 하도록 조작한 뒤 생주의 뇌에 이식시켜 자라게 하고, 종양을 고사시키는 TRAIL(Tumor Necrosis Factor related Apoptosis inducing Ligand)을 분비하도록 만든 신경줄기세포가 반딧불이 루시페라제를 발현하도록 만든 뒤 뇌종양의 주위에 이식시켰다. 기질인 반딧불 이 루시페린을 복강 내에 주사한 후 영상을 얻어 신경 줄기세포가 증식하면서 종양을 향해 이주하는 모습을 관찰할 수 있었고, Renilla 루시페린을 정맥 주사한 후 영상을 얻어 신경줄기세포에서 분비되는 TRAIL에 의 
해 종양의 크기가 줄어드는 모습을 얻을 수 있었다고 보고하였고 ${ }^{[14]}$, 추가 실험에서 고사의 진행에 중요한 효소인 caspase에 의해 특정 부위가 잘려야만 루시페라 제에 의해 빛을 낼 수 있도록 변형된 기질인 DEVD-lucifenin을 복강 내에 주사하여 얻은 caspase 활 성도 영상을 통해서 크기가 줄어들고 있는 종양에서 고사가 광범위하게 진행되고 있음을 확인할 수 있었 다고 보고하였다 ${ }^{[14]}$.

생물발광영상이 앞으로 극복하여야 할 문제는 어떻 게 임상에서 이용할 수 있도록 만들 것인가 라는 점이 다.

이를 위하여 MRI(Magnetic Resonance Imaging), CT(Computed Tomography), PET(Positron Emission Tomography)등과 결합함으로써 상호 단점을 보완하는 방법이 있을 수 있고 ${ }^{[9]}$, 영상화를 위한 가시광선을 더 많이 방출하는 루시페라제를 개발하는 노력도 필요할 것이다.

\section{2. 형광영상(fluorescence imaging)}

형광영상은 생체 내의 세포, 조직에 있는 형광물질 이 외부에서 조사되는 빛을 흡수하여 흥분상태 (excitation state)가 되어 입사되는 빛 보다 긴 파장의 빛을 방출(emission)할 때 이를 감지하여 영상화하는 방법이다 ${ }^{[7]}$.

형광영상 보고자(fluorescence labeled reporter)는 방사 성동위원소(radioisotope)를 사용하는 핵의학 영상과 달 리 방사선을 이용하지 않기 때문에 오랜 시간 또는 반 복적인 영상획득이 필요한 경우 유리한 장점이 있는 반면, 방출되는 가시광선이 방사성동위원소에서 방출 되는 감마선보다 투과도가 낮아다는 단점이 있다. 이 러한 단점을 보완하기 위하여 형광영상과 핵의학영상 기술을 결합하는 방법이 있을 수 있고, $\mathrm{MRI}$ (magnetic resonance imaging)을 위한 조영제와 형광물질을 결합하 여 사용하는 방법이 있을 수 있다 ${ }^{[15]}$.

형광물질들 중에서 흥분(excitation) 후 발산하는 가 시광선의 스펙트럼이 적외선에 가까운 것일수록 (700 900 nm : 근 적외선, near infrared) 생체 투과율이 높기 때문에 이에 대한 연구가 많이 진행 중에 있다 ${ }^{[8]}$.

Fig. 1은 $\mathrm{C} 57 \mathrm{BL} / 6$ mouse에 뇌 좌상(contusional injury)을 가한 후 5일 지난 다음 정맥 주입된 형광보고 자(fluorescent reporter)가 병변 주위 대식세포의 cathepsin 효소에 의해 활성화되어 발산하는 근 적외선 빛(적색)을 두 개 창문(cranial window)을 통해 포착한 영상이다.

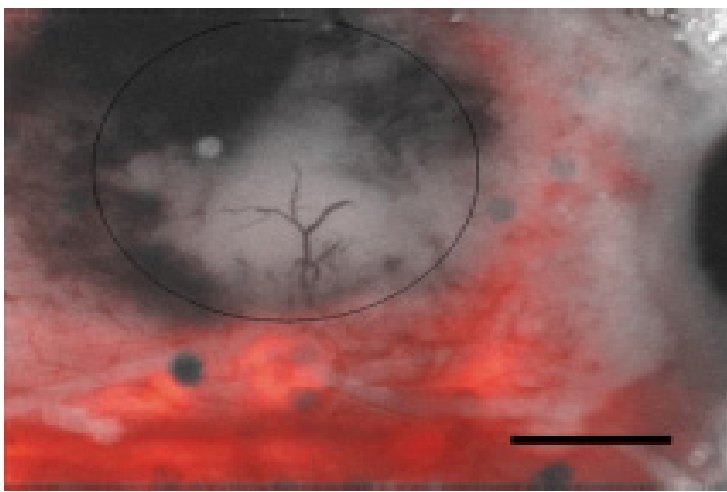

Fig. 3. Molecular imaging using fluorescent.

대부분의 형광영상은 하나의 광원(ight source)에서 나오는 광선을 이용해 생체 내의 형광물질을 흥분시 킨 후 방출되어 나오는 빛을 하나의 빛 탐지기(light detector)로 기록하거나 영상화하는 반사 영상 (reflectance imaging)이다. 이에 비해 생체를 둘러싸는 많은 광원과 빛 탐지자들을 이용해 얻어낸 수많은 영 상을 생물학적으로 모델링(biophysical computer modeling)하여 단층영상을 만들어 낼 수 있는데, 이것 이 형광단층영상술(fluorescent mediated tomography)이 다 ${ }^{[16]}$. 이 영상기술능 형광물질 분포의 3 차원 재구성을 가능하게 할 뿐만 아니라 반사 영상에 비해 더 깊은 곳에 있는 생체 내의 형광물질을 탐지해 낼 수 있게 해준다.

광학적 단층영상 기술의 발전이 큰 영향을 발휘할 수 있는 분야들 중 하나로 유방암의 영상진단 분야이 다 ${ }^{[17]}$. 그리고 광학영상의 미래를 밝게 하는 연구결과 들 중 영상화를 목표로 하는 특정 효소에 의해서만 반 응하여 활성화되는 형광보고자(fluorescent reporter)의 개발이다. Weissleder 그룹에서 개발한 cathepsin B probe ${ }^{[18]}$ 나 MMP(matrix metalloproteinase) probe ${ }^{[19]}$ 가 대 표적인 예이다. 항상 시그널을 발산하기 때문에 영상 화를 목표로 하는 생리적인 그리고 병리적인 현상 외 에도 혈류량과 혈류분포에 의해 쉽게 영향을 받는 켜 
있는 probe(on probe)들과는 다르게 위에 열거한 probe 들은 cathepsin $\mathrm{B}$ 나 $\mathrm{MMP}$ 와 같은 특정 단백분해효소가 probe의 특정 부위를 잘라 주어야만(proteolysis) 형광 시그널을 발산한다. 따라서 종양과 기타 각종 염증 부 위에 집결한 대식세포(macrophage)가 생산하는 cathepsis B 효소의 활성도(Fig. 1)나 종양의 전이와 허 혈성 심장 뇌 손상 등에서 중요한 역할을 하는 $\mathrm{MMP}$ 효소의 활성도를 영상화할 수 있게 된다. 암이 될 위 험이 높은 대장 폴립(precancerous polyp)의 경우 cathepsin B 효소의 활성도가 높다는 점에 착안하여 cathepsis B probe에 대한 임상시험이 시행되어 $1 \mathrm{~mm}$ 이하의 병변을 찾아낼 수 있을 것으로 기대하고 있다 [9].

광학영상은 소화기내시경, 혈관내시경 및 복강경 등 다양한 종류의 내시경과 결합되어 발전하고 있다 [14]. 예를 들어 종양수술 전에 형광물질을 정맥주사하 여 병변을 선택적으로 표지(labeling)하면, 수술시 형광 현미경(intra operation fluorescent microscopy)을 통해 종 양의 경계를 보다 정확히 구분할 수 있게 된다 ${ }^{[20]}$.

\section{2. 핵의학 분자영상}

방사선과학 분야에서 분자영상의 정의는 “특정세 포, 수용체, 유전자 등에 선택성이 있는 분자 또는 나 노 크기의 조영제나 발광제를 이용하여 장기의 기능 적 영상을 $\mathrm{CT}, \mathrm{MRI}$, 초음파, 광학장비 등으로 영상을 얻는 것" 이라고 정의할 수 있다.

핵의학 영상은 방사성의약품을 이용하여 특정 세포 나 수용체 등에 대사과정을 거쳐서 선택적으로 섭취 된 부분을 영상으로 나타내기 때문에 분자영상이라고 할 수 있다. 핵의학 분자영상은 $\gamma$-카메라, SPECT, $\mathrm{PET}$, Fusion장비 등에 의하여 획득된다.

\subsection{PET(Positron Emission Tomography)를 이 용한 분자영상}

PET는 양전자를 방출하는 방사성의약품을 체내에 투여한 후, 투여된 물질의 분포를 영상화한다. PET용 방사성동위원소는 생물학적 주요 구성 성분인 불소 (18F), 탄소(11C), 산소(15O) 등을 이용한다. 이들 양전 자 방출 방사성동위원소를 이용하여 화학적 성질의
변화 없이 체내 성분대사, 약물대사, 수용체 등을 영상 으로 만든다. PET는 수 피코 몰(pico Mole) 정도의 낮 은 농도의 추적자도 관찰할 수 있으며 정량화가 된다 는 장점을 가지고 있다. 아래의 Table 2는 PET를 이용 한 영상기법과 방사성의약품을 나타내고 있다.

Table 2. Radiopharmaceuticals for PET

\begin{tabular}{|c|c|}
\hline Mode of action & Radiopharmaceut icals \\
\hline $\begin{array}{l}\text { Substrate } \\
\text { metabol ism }\end{array}$ & F-18 FDG, 0-15 02, C-11 acetate, C-11 chol ine \\
\hline Protein synthesis & C-11 methionine, $C-11$ tyrosine \\
\hline DNA synthesis & C-11 thymidine, F-18 FLT, F-18 FMAU \\
\hline Bone remodel I ing & F-18 fluoride \\
\hline $\begin{array}{c}\text { Mi tochondr ial } \\
\text { membrane } \\
\text { potent ial }\end{array}$ & $\begin{array}{l}\text { F-18 TPP (tetrapheny Iphosphonium) } \\
\text { C-11 TPMP (tr iphenyImethyIphosphonium) }\end{array}$ \\
\hline Hypoxia & F-18 FMISO \\
\hline Enzyme activity & C-11 deprenyl, F-18 deoxyuracil \\
\hline Drugs & C-11 cocaine, $\mathrm{N}-13$ cisplatin, $\mathrm{F}-18$ fluorouracil \\
\hline Receptor affinity & C-11 raclopr ide, C-11car fentani I, F-18 FP-Gluc-TOCA \\
\hline $\begin{array}{l}\text { Neurotransmitter } \\
\text { biochemistry }\end{array}$ & F-18 fluor odopa, F-18 FESP, C-11ephedr ine \\
\hline Gene expression & $\begin{array}{c}\text { F-18penciclovir, I-124 FIAU, F-18ant isense } \\
\text { ol igonucleotides }\end{array}$ \\
\hline Antibodies & I-124 ant i-CEA minibody, Cu-64 ant i-Her2 minibodies \\
\hline
\end{tabular}

포도당에 양전자를 방출하는 방사성동위원소(18F) 를 표지한 것이 암 환자의 진료에 활발히 시행되고 있 는 FDG (fluorodeoxyglucose) PET검사이다. FDG를 환 자의 몸에 주사하고 PET를 이용하여 스캔하면 암세포 와 같이 포도당 대사가 증가된 병소를 조기에 진단할 수 있다. 이러한 검사 방법이 모든 암을 다 찾아내는 것은 아니다. 왜냐하면 포도당을 활발하게 이용하지 않는 암세포는 이 검사법에서도 잘 나타나지 않기 때 문이다. 대부분의 암은 포도당을 활발하게 이용하기 때문에 이 검사 방법의 유용성이 있다고 할 수 있다. 포도당 대사과정을 이용하는 FDG PET 스캔은 분자 영상을 얻는 것이다. FDG를 이용한 PET 검사는 현재 까지 시도된 어떤 진단 방법보다도 암의 진단율, 특히 조기 발견이 우수하다. 그러나 FDG를 이용한 PET 검 사 방법도 염증을 유발하는 암조직, 즉 염증과 공존하 는 병소를 감별하는 데는 약점이 있어서 이를 보완할 
수 있는 방사성의약품의 개발이 요구된다.

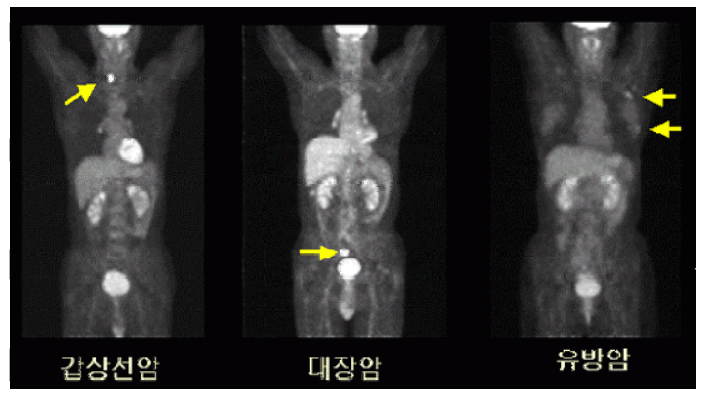

Fig. 4. PET scan images by using FDG.
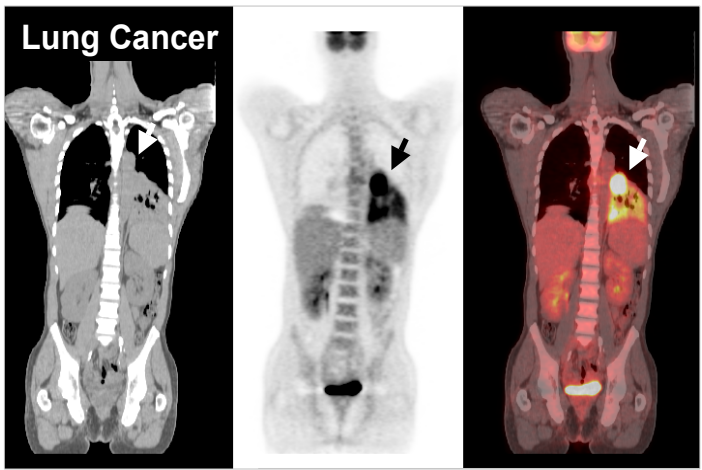

Fig. 5. PET-CT images.

2.2. $\gamma$-Camera와 SPECT(Single Photon Emission Computed Tomography)

감마카메라와 감마카메라를 이용하여 단층촬영을 하는 SPECT는 PET와 달리 양방향에서 감마선을 수신 하지 않음으로 신호가 약해 민감도가 PET에 비해 $1 \%$ 정도 밖에 되지 않는다. $99 \mathrm{mTC}$ 등 SPECT에 사용되는 방사성의약품은 분자구조를 변형시켜야 하는 경우가 많기 때문에 PET에 비해 늦게 개발이 되었다. 그러나 최근에 항체치료제, 세포치료제, 나노치료제 등의 연 구가 증가하고 있고, 약물역동 및 효과를 측정하기 위 하여 장시간 추적을 하여야 하는 수요가 늘어나고 있 어서 감마카메라와 SPECT를 이용한 분자영상의 연구 는 계속된 증가가 예상된다. 특히 바이오신약 개발을 위한 분자영상에서는 바이오신약이 분자량이 커서 표 지하는 방사성동위원소의 크기에 구애받지 않는다. 따 라서 저에너지의 ${ }^{125} \mathrm{I}$ 방사성동위원소를 이용하여 마우
스와 같은 소동물에서 장기간 측정이 가능하다.

\section{MRI 분자영상}

자기공명영상은 핵의 스핀(spin)이 자기장 내에서 일으키는 공명현상을 이용하여 영상을 얻는 기술이다. 자기공명영상 장비는 안전성이 높고 영상의 해상도도 좋다. 그래서 연부조직의 영상 대조도가 우수하여 임 상에서 질병의 진단을 위하여 없어서는 안 되는 중요 한 영상기법으로 자리 잡고 있다. 특히 다양한 조영제 의 개발과 질환 특이적 영상 조영제에 대한 연구가 꾸 준히 보고되고 있어 자기공명영상법을 이용한 분자영 상 기법의 중요성도 부각되고 있다.

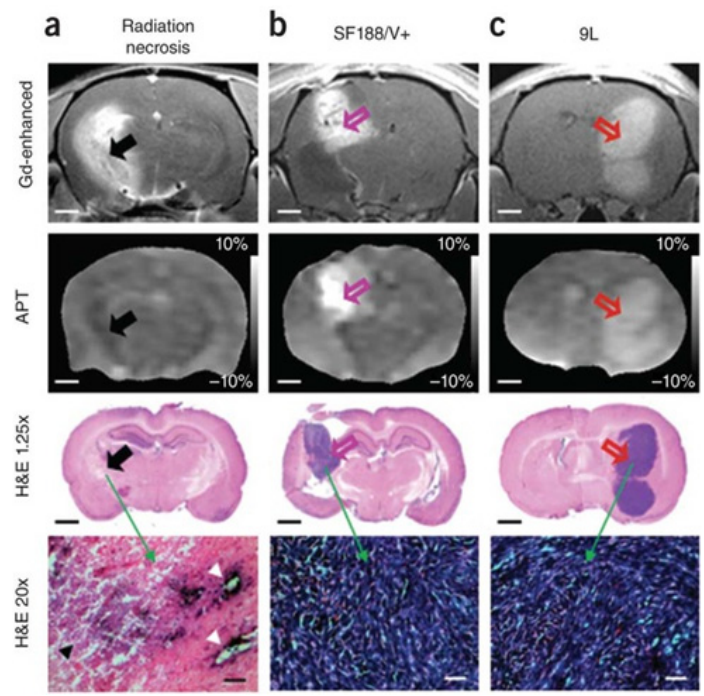

Fig. 6. MR Molecular Imaging

그러나 자기공명영상은 해상도는 매우 뛰어나지만 분자영상을 위하여 중요한 민감도가 핵의학 영상에 비하여 떨어진다. 그래서 민감도 부족 부분을 극복하 기 위하여 많은 연구가 진행 중에 있다 ${ }^{[21]}$.

자기공명영상법의 획기적인 발전 중에 과분극 (hyper-polarization)이라는 것이 있다. 과분극 기법은 자 기공명신호를 1000 10,000배 까지 증가시키는 방법이 다. ${ }^{3} \mathrm{He},{ }^{129} \mathrm{Xe},{ }^{13} \mathrm{C}$ 등 자기공명신호가 수소에 비해 매 우 적은 원자들을 과분극하여 가능한 수준으로 신호 를 증가 시킬 수 있다. ${ }^{3} \mathrm{He},{ }^{129} \mathrm{Xe}$ 는 인체에 무해한 불 활성 기체로서 허파영상을 위한 과분극을 한다. ${ }^{13} \mathrm{C}$ 는 동위원소이지만 매우 안정적이고 자연 존재비는 $1 \%$ 
수준이며, 자기공명신호는 수소와 비교하여 $1.5 \%$ 정도 이다. 탄소는 생체 내에 다량 존재하지만 ${ }^{13} \mathrm{C}$ 의 자연 존재비와 신호강도를 고려해 보면 과분극되지 않은 ${ }^{13} \mathrm{C}$ 으로 부터는 영상신호를 얻을 수가 없다. 그래서 과 분극된 ${ }^{13} \mathrm{C}$ 을 생체 내에 주입하면 주입한 ${ }^{13} \mathrm{C}$ 만 신호 를 만들고 이것 또한 영상 추적자로서의 역할을 하게 된다. ${ }^{13} \mathrm{C}$ 를 이용하여 에너지 대사를 실시간으로 영상 화하고자 하는 연구는 ${ }^{13} \mathrm{C}$-피부르산염(pyruvate)을 정맥 주사하여 이 물질이 젖산(lactate)으로 변해나가는 것을 실시간으로 모니터링하고 피브르산염과 젖산의 비 (ratio)를 구하여 암치료 효과를 영상으로 모니터링하 는 기법이 보고되고 있다 ${ }^{[22]}$.

자기공명영상법은 분자영상에서는 다소 불리한 점 도 있지만 안전성과 우수한 영상의 품질 때문에 분자 영상에 많은 연구기 진행되고 있다. 자기공명영상법을 이용한 분자영상은 질한 특이적인 물질들을 결합하여 질환의 진단 또는 줄기세포, 면역세포 등을 추적하는 연구들이 수행되어 왔고, 최근 들어 에너지 대사과정 의 모니터링 등을 구현하였다. 현재의 자기공명 시작 단계라고 할 수 있을 것이다.

\section{4. 초음파분자영상}

초음파를 이용한 분자영상은 초음파 영상 조영제인 마이크로 버블을 조영제로 사용하여 혈관 및 목표장 기를 추적하는 분야로 발전해 왔다. 초음파 조영제는 1969년에 Gramiak과 Shah가 생리적 식염수를 경정맥 주사한 후 심장초음파 검사에서 초음파 신호강도가 증가한다는 보고를 한 이후에 약 30년간에 걸쳐서 발 전되어 오고 있다 ${ }^{[23]}$. 초음파 조영제는 선형 및 비선형 특성에 의하여 SNR을 높여주며, 이에 따라 내부 장기 와 혈관을 더 정확하게 진단할 수 있게 한다 ${ }^{[24]}$. 초음 파 조영제는 혈관 내에서 안정적으로 존재할 수 있는 마이크로 기포(micro bubble)로써 초음파가 전달되는 영역 내에서 반사신호를 높여 SNR의 향상시킨다. 그 리고 기포가 확장할 때와 수축할 때의 비선형 운동적 공명진단을 하며, 이러한 비선형 운동의 음파를 탐촉 자(transducer)가 검출하면 하모닉 영상을 얻을 수 있다. 비선형 성분을 영상화 하는 기법을 contrast harmonic imaging이라 하고 최근에는 그 사용이 증가하고 있다 [25]-[26]. 최근에는 초음파 조영제를 활용하여 치료용 초
음파의 수술 효과를 높이려는 시도가 이루어지고 있 다. 약물에 함유된 초음파 조영제를 특정 혈관이나 조 직에서 초음파를 이용하여 파열시키면, 효과적인 약물 투여 효과를 얻을 수 있다. 더불어 초음파 조영제는 초음파 공동 효과를 조절할 수 있기 때문에 공동 현상 을 이용하는 초음파 암 수술 효과를 개선하는 용도로 도 활용할 수 잇을 것이다. 초음파 영상 조영제는 목 적하는 방향에 따라 여러 방향으로 개발이 진행 중이 다. 최근에는 특정 세포만을 결합할 수 있는 ligand binding site를 첨가하여 개발된 조영제도 있다 [27]-[28]. 이상적인 초음파 영상 조영제는 독성이 없어야하고, 혈관으로 주입 가능하여야 하며, 폐의 모세혈관 내를 자유롭게 통과할 수 있도록 크기가 $10 \mu \mathrm{m}$ 보다 작아야 한다. 또한 오랫동안 사용하기 위해서 안정성이 높아 야한다. 초음파 영상 조영제의 안정성을 확보하기 위 하여 Shell로 보호된다. Shell 물질로는 생체 내에 존재 하는 albumin 등의 단백질이나 lipid 물질이 사용되고 있으나, 최근에는 폴리머 활용이 연구되고 있다[29].

\section{III. 분자영상의 적용분야}

\section{1. 유전자 치료 모니터링}

치료 목적으로 전달한 유전자가 표적 세포 내에 적 절히 발현하는 것이 유전자 치료에서 가장 중요한 문 제이다. 치료 유전자의 발현 여부를 PET이나 과학 리 포터 유전자를 통하여 간접적으로 예측하는 방법 개 발되었다 ${ }^{[19]}$. 이 방법에서 리포터 유전자 발현의 정량 치는 치료 유전자 발현의 양을 정확히 반영할 수 있어 야 한다. 이 방법의 장점은 여러 치료 유전자와 리포 터 유전자를 결합시킬 수 있으므로 치료 방법에 따라 다양하게 적용할 수 있다는 것이다.

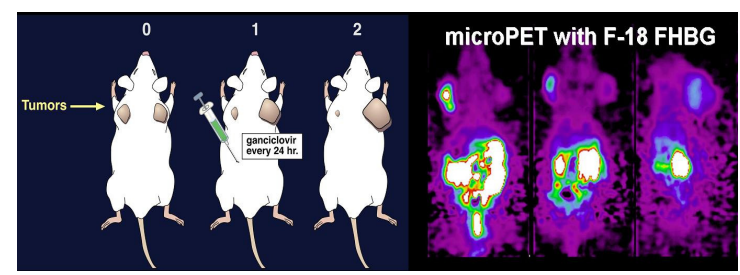

Fig. 7. Monitoring gene therapy using microPET with F-18 FHBG (reporter probe for HSV1-tk) while treating a HSV1-tk expressing tumor with ganciclovir. 


\section{2. 세포추적(Cell trafficking)}

세포를 체외에서 표지하여 체내 투여하면 전이, 줄 기세포 이식, 림프구의 반응 등 세포의 이동을 추적하 여 영상화 할 수 있다 ${ }^{[30]}$. FDG는 염증세포에도 잘 섭 취되므로 단핵세포(monocyte)의 체내이동을 추적한 연 구가 국내에서 시행된 바 있으며, HSV1-tk리포터 유전 자를 주입한 $\mathrm{T}$ 림프구를 투여하여 항암반응을 micro-PET를 이용하여 영상화하였다. 이 방법으로 세 포의 이동경로와 생존정도를 평가함으로서 병리를 이 해하고 항암이나 면역치료의 평가에 사용할 수 있을 것이다.

\section{3. 세포 치료 모니터링}

줄기세포(stem cell)나 전구세포(progenitor cell)를 이 용한 치료의 개발이 대두되고 있다. 분자영상은 이러 한 세포치료의 모니터링에도 사용할 수 있어 전달된 세포가 잘 정착이 되었는지 또 얼마나 오래 살고 있는 지를 평가할 수 있다.

$\mathrm{Wu} \mathrm{J}$. 등은 배아 심장근육세포(embryonic cardiomyoblast) 에 HSV1-tk 유전자를 넣은 다음 쥐의 심장근육에 주입 한 후 살아있는 상태에서 micro-PET으로 추적하여 촬 영을 하였다. 염증, 허혈, 고사 등의 원인으로 첫 4일 동안 급격한 세포의 격감을 추적할 수 있었으며 이는 조직검사를 통한 다른 연구에서도 나타났다 ${ }^{[31]}$. 분자영 상은 이러한 생체 내에서 반복적 추적(longitudinal) 검 사를 함으로써 적절한 새포종류의 선정, 세포량의 결 정, 주입방법, 세포를 오래 살릴 수 있는 약제의 선정 등 세포치료의 개발을 최적화할 수 있으며, 임상실험 에서도 사용할 수 있다.

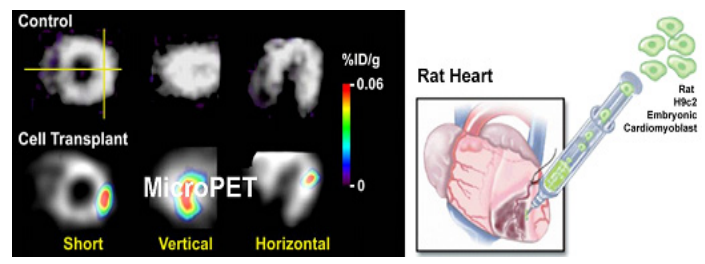

Fig. 8. Monitoring cardiomyoblast cell therapy using microPET.

\section{4. 항체영상}

항체영상은 감마카메라나 SPECT를 이용하여 많은 시도가 있었으나 영상의 질이 낮아 실제 임상에서는 흔히 쓰이지는 않는다. 이는 온전한 항체의경우 혈중 에 오래 남아 있어 배후 방사능이 높기 때문이다. 최 근 항체의 $\mathrm{Fc}$ 부분 일부를 제거한 미니항체(minibody) 등을 만들어 항원인식 기능은 유지한 체 혈중 제거 속 도를 높여 영상에 적합하게 만드는 시도를 하고 있다. UCLA의 Wu A. 등 ${ }^{[2],[27]}$ 은 $\mathrm{Cu}-64$ 나 I-124에 CEA 미니항 체를 붙여 생쥐에서 microPET영상을 얻었으며 $\mathrm{HER} 2 / \mathrm{neu}$ 미니항체를 만드는 시도를 하고 있다.

\section{5. 분자 상호작용 영상}

\section{(Molecular Interaction Imaging)}

세포 내 입자간 상호작용을 영상화하는 예들, 즉 GAL4-VP16의 상호작용을 영상화하는 방법은 TSTA (two step transcription amplification)시스템에 관한 연구 는 최근 많은 논문을 통하여 밝혀져 왔다. 단백질들의 상호작용을 규명하는 것은 세포 내에서 일어나는 신 호전달 등의 생물학적 기전을 규명하거나, 약물 작용 의 기전을 규명하는데에 있어 중요성을 갖는다. Ray 등은 NF-kB 프로모터로부터 유도되는 두개의 융합 단 백질(VP16-MyoD와 GAL4-ID)이 서로 결합하여 작용하 는 것을 입증하였다. Paulmurugan 등은 상호작용을 알 고자하는 단백질의 하방에 분리 리포터를 붙이는 방 법을 이용하여 두개의 단백질이 상호 작용하는 것을 영상화하였다.

\section{6. 근 적외선 형광 물질(Near-infrared \\ fluorescent dye)을 이용한 암 형광 영상법}

암 특이 단백질 분해 효소인 cathepsin B \& $\mathrm{H}$, matrix metalloprotease-2 (MMP-2) 등에 의해 활성화되는 근 적 외선 형광 프로우브들이 개발되어 실험되고 있다. 같 은 에너지를 갖는 두 개의 형광 물질이 수 $\mu \mathrm{m}$ 의 근접 된 거리에서는 외부에서 여기를 시켜도 에너지를 주 고 받아 소등된(quenched) 상태로 있다. 하지만, 이들의 간격이 넓어지면 점등(unquenched) 상태로 변환되어 영상 신호를 만들 수 있다. 그래서 indocyanine green 
(ICG)나 cy5.5와 같은 fluorescent dye를 종양 특이 단백 분해 효소에 약한 아미노산 배열로 연결시킨 프로우 브 구조를 제작하여 종양에 주입하면 특정 단백 분해 효소가 없으면 소등되어 있고, 있으면 점등되는 영상 을 얻을 수 있다.

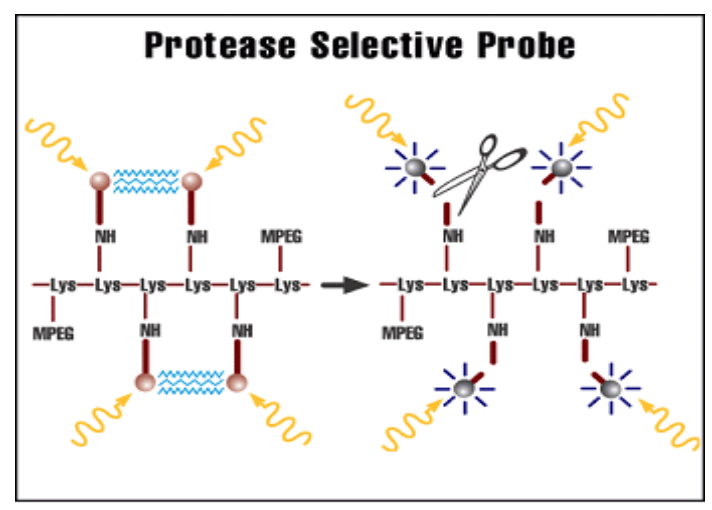

Fig. 9. Tumor specific enzyme selective probe.

\section{Bacteria 를 이용한 종양 표적 영상}

(Imaging active tumor targeting by Lightemitting bacteria)

In vivo bioluminescence 영상은 세균 감염 모델을 가 지고 처음 개발되었었다 ${ }^{[5]}$. 이 모델에서는 bacterial luciferase (Lux)를 통하여 빛을 만들어내는 soil bacterium Photorhabdus luminescens의 lux operon을 살모 넬라 균에 도입하였다. 다섯 개의 유전자로 구성되어 있는 lux operon은 하나의 프로모터로부터 5 개의 유전 자를 코딩하고 있는데, lux A, B 두개의 유전자는 luciferase 효소를 생산해내고, lux C, D, E는 3 개의 기질 을 합성하는 효소를 생산한다. 따라서 이 방법에서는 firefly luciferase를 사용할 때와는 달리 기질을 외부로부 터 주입해 줄 필요가 없다. 이러한 lux의 반응을 통하 여 약 $500 \mathrm{~nm}$ 의 푸른색 빛이 방출된다.

이러한 '빛나는 박테리아(light-emitting bacteria)'는 세 균의 체내의 동태를 파악하거나, 이식된 골수세포나 줄기세포의 세균 감염에 대한 생존력 등을 판단하는 데 이용되어왔다. 최근에 필자의 실험실에서는 대장균 에 lux operon을 형질 전환하여 종양 세포를 표적하는 지 여부를 광학 영상을 통하여 입증하고 있다. 형질 전환된 '빛나는 대장균'은 피하 종양이 이식된 마우스
의 정맥을 통하여 주사되었는데, 주사 후 첫날은 주로 간에 모여있다가 주사 후 이틀째부터 종양 조직으로 이동하여 생존하고 분열하는 것을 관찰할 수 있었다. 향후 종양 영상 및 치료 목적으로 종양 세포를 선택적 으로 표적할 수 있는 물질로 개발될 예정이다.
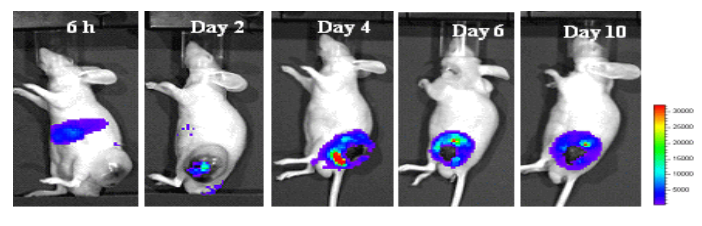

Fig. 10. Active tumor targeting of bacteria. Optical imaging CT 26 xenograft tumor mouse after injection of light-emitting E. coli.

\section{8. 치료효과 조기 평가}

FDG PET은 세포막에 존재하는 포도당운반체 (GLUT1)와 세포내 6탄당대사효소(hexokinase)의 활성 도에 따라 방사성불소(F-18)가 표지된 탈산소포도당 (deoxyglucose)이 인산화되어 세포내에 축적되는 기전 을 영상화하는 기법으로 포도당 해당대사(glicolysis)의 활성도를 반영한다. 해부학적 영상을 추적하는 CT나 $\mathrm{MRI}$ 에 비해 방사선치료 및 화학요법 후 조기에 반응 을 평가할 수 있어 임상시험 프로토콜에서 조기 치료 반응 평가용 대리표지자로 활용하고 있다. 특히 암세 포에 있는 특정 바이오마커를 표적하여 치료하는 수 용체티로신키나아제(receptor tyrosine kinase; RTK)계열 신약은 세포를 죽이지 않고 증식을 억제하므로 기존 의 CT나 MRI 등에서 측정하는 종양 크기 변화로 효과 를 평가하기 어렵다. 반면 GIST치료에 글리벡(imatinib mesylate)을 사용하면 하루 만에 포도당대사가 감소하 는 것을 FDG PET 인체영상으로 확인할 수 있으며, 동물영상에서는 2 시간 만에 감소하였다. 같은 기간 CT 에서는 종양의 크기변화를 볼 수 없었으며 표적치료 제의 선택을 조기에 결정하는 데 큰 역할을 할 것으로 기대된다.

F-18 FLT는 티미딘(thymidine)유사체로 세포막에 위 치한 티미딘전달체를 통해 세포 내로 들어가며 활발 히 증식하는 세포에 더 많이 축적되는 경향이 있다. 악성림프종 환자에서 FLT의 표준섭취계수(SUV)는 조 직에서 세포증식을 반영하는 면역화학염색마커인 
$\mathrm{Ki}-67$ 과 양성 상관관계를 보였다. FDG에 비해 악성종 양에서 SUV는 낮으나 염증세포 등 비특이적 섭취가 낮아 P-cadherin 억제제 등 세포증식 상태를 평가하는 신약 임상시험에 활용되고 있다.

세포의 저산소 상태를 평가하는 [18F]FMISO, 64Cu-ATSM PET 등은 방사선 및 화학요법에 저항성이 강한 암조직 부위를 나타내며 PET을 이용한 방사선치 료계획, 분획치료후 재산소전달(reoxygenation), 항신생 혈관치료제의 혈관재구성 정도를 평가할 수 있다.

세포자멸사는 심근경색, 화학요법 등으로 인해 발 생하는데, caspase 분해효소가 활성화되고 phosphatidylserine(PS)이 세포외막에 노출된다. 세포자 멸사를 영상화하기 위해 활성화된 caspase나 노출된 PS 를 표적으로 하는 annexin A5 PET가 개발되었다. 세포 자멸사 PET영상은 뇌, 심근 허혈의 재관류 치료효과 평가, 화학요법제 효과의 조기 평가, 장기이식 거부 조 기평가 등 각종 질병의 진단과 치료효과 평가 등에 활 용할 수 있다.

\section{9. 치료 효과 예측}

최근 개발되고 있는 특정한 바이오마커를 표적으로 하는 신약은 고가이면서 해당 바이오마커를 발현하고 있는 일부의 환자만이 반응을 한다. 상피성장인자수용 체(EGFR, HER2)를 표적으로 하는 어비툭스 (cetuximab), 허셉틴(trasttuzumab), 이레사(gefitinib), $\mathrm{CD} 20$ 항원을 표적으로 하는 악성림프종 치료제 리툭 산(retuximab), 제발린(Y-90 ibritumomab), 신생혈관생성 을 억제하는 아바스틴(bevacizumab), 수텐트(sunitinib), 넥사바(sorafenib)등 특정 바이오마커 표적 항체 또는 소분자 약물이 이미 임상에 사용 중이며 c-MET, MAGE-A, MUC1, p-Cadherin, ALK 등의 바이오마커를 표적으로 하는 신약이 개발 중이거나 임상시험 중이 다. 이들 약물은 환자의 5 30\%의 일부에서만 발현되 어 이를 찾는 것이 매우 중요하다. 이러한 표적치료제 의 효과를 미리 예측하여 대상 환자를 선별하는 방법 을 동반진단검사(companion diagnostics)라고 한다.

허셉틴의 경우 유방암조직에서 $\operatorname{Her} 2$ 과발현 여부를 평가하기 위하여 생검 조직에서 항 Her2항체로 면역화 학염색을 하여 암세포 표면의 $\operatorname{Her} 2$ 단백의 과발현을
보거나 형광동소보합법(fluorescence in situ hybridization, $\mathrm{FISH})$ 을 사용하여 $\mathrm{Her} 2$ 유전자의 과발현을 평가한다. 비소세포성 폐암치료제인 이레사의 경우 서양인에서 는 효과가 적은데 비해 동양인 비흡연자에 효과가 있 어 연구를 한 바 유전체 검사를 통하여 유전자의 변이 로 EGFR RTK 과발현이 있는 경우만 효과가 있음을 밝혔다. 이에 Her2 과발현을 영상화하는 I-124 허셉틴 $\mathrm{PET}, \mathrm{RTK}$ 에 이레사보다 더 강하게 부착되는 morpholino-[I-124]-IPQA (iodophenyl quinazoline)를 이용 한 PET가 임상연구 중이다.

조직염색 또는 약물유전체 검사를 이용하고 있음에 도 불구하고 $\mathrm{PET}$ 와 같이 인체영상을 필요로 하는 이 유는 원발암조직과 전이암조직간의 바이오마커 발현 의 차이, 심지어 한 조직 내에서도 부위에 따라 다르 게 나타나기도 한다. 따라서 개인 맞춤형 치료 (personalized therapy)에서 더 나아가 부위별 맞춤치료 (lesionalized therapy)를 해야만 완치를 꿈꿀 수 있다. 치 료제에 집적 방사성동위원소를 표지하여 $\mathrm{PET}$ 영상화 를 시도하고 있지만 항체의 경우 혈중 반감기가 길어 신호대배경비(signal to noise ratio)가 나쁘며 소분자약 물의 경우 방사성동위원소 표지가 화학적 성질을 바 꿀 수 있고 해당 표적에 대한 섭취능력이 떨어지는 경 우가 있다. 이를 개선하기 위하여 항체의 경우 항체의 $\mathrm{Fc}$ 부분 일부를 제거한 미니항체(minibody) 등을 만들 어 항원인식 기능은 유지한 체 혈중 제거 속도를 높여 영상에 적합하게 만드는 시도를 하고 있다. 장반감기 PET용 동위원소인 $\mathrm{Cu}-64$ 나 I-124에 HER2/neu 미니항 체를 표지하여 PET영상을 얻는 연구를 하고 있다.

신생혈관억제제의 경우 아직 조직적으로 치료반응 을 예측하는 방법이 없다. RGD(arginine-glycine-aspartic acid) 펩타이드는 신생혈관세포 표면에 과발현되는 intergrin $a_{v} \beta 3$ 과 결합하는 리간드 비트로넥틴 (vitronectin) 단백질의 결합부위로 이를 이용한 PET영 상법이 개발되었다. Ga-68 RGD PET영상은 정상인에 서 작은 분자량으로 인해 주사후 30 분이내 대부분 신 장을 통해 배설되어 신장, 방광을 제외하면 다른 장기 에는 낮은 섭취를 보인다. 17명의 아바스틴을 포함한 항암치료 환자군에서 시행한 치료전 Ga-68 RGD PET 는 치료효과를 예측하였다. 


\section{0. 신약 개발}

약제 개발은 많은 시간과 돈이 드는 일이다. 지금까 지 전임상시험으로는 H-3나 C-14과 같은 동위원소를 이용하여 동물의 조직을 채취하여 생체분포 (biodistribution)를 보거나 약효를 평가하였다. PET는 약의 분포, 배설, 동태(pharmacokinetics) 뿐만 아니라 효 과까지 평가할 수 있어 새로운 약의 개발에 돈과 시간 을 절약할 수 있게 한다.

방사성표지가 된 항암제, 도파민 수용체나 에스트 로젠 수용체 등 수용체 영상, F-18 PEGylated RGD (Arg-Gly-Asp) peptide와 같은 혈관생성(angiogenesis) 영 상 등 새로운 방사성의약품을 이용한 연구도 활발하 나 이미 임상에서 많이 사용되는 F-18 FDG 소동물 PET을 이용하여 새로운 항암제의 효과를 평가하는 방 법도 활발하다. FDG를 이용한 약제 평가는 동물에서 뿐만 아니라 임상시험으로 이어질 수 있다는 장점이 있다.

더 나아가 의학적 임상적용 전에는 안전성/유효성 검증을 위하여 독성시험, 생체분포, 진단성능 평가 등 전임상시험 과정이 필요한데 나노입자는 수일에서 수 주 동안 생체 내에 머물러 장반감기 PET용 방사성동 위원소를 이용한 영상화가 꼭 필요하다.

신약에 방사성동위원소를 표지한 PET 영상을 이용 하여 방사성신약의 체내분포를 추적함으로써 신약의 전신장기 및 표적부위 약동학을 평가할 수 있다. 다만 방사성동위원소 표지 신약이 화학적, 약리학적으로 신 약과 동일하여야 한다는 전제가 필요하다. 방사성동위 원소가 표지된 약물을 체내에 투여한 후 동적(dynamic) PET영상을 얻으면 체내분포, 배설경로, 생물학적 반감 기를 평가할 있다. 신경계 작용하는 약물을 개발할 경 우 뇌혈류장벽(blood brain barrier; $\mathrm{BBB}$ )을 통과하는 정 도를 PET영상으로 평가하여 지용성 정도를 최적화할 수 있다. 동물뿐만 아니라 인체에서도 방사성표지 신 약을 투여하여 동적 PET영상을 얻으면 인체에서 약동 학을 평가할 수 있다. 마우스 등 소동물PET를 이용한 약동학 평가는 저렴하고 간편하게 시행할 수 있으나 인체에 비해 대사 및 배설 속도가 빠르고 체내분포 및 배설경로가 다른 경우도 있다. PET는 극미량의 약물
도 영상화할 수 있어 약효가 예측되는 용량의 $1 / 100$ 또는 $100 \mathrm{\mu g}$ 이하를 투여하는 마이크로도싱 (microdosing) 검사를 할 수 있다. 이정도의 용량은 약 물이 독성을 띤다 하더라도 인체에 독성을 나타낼 가 능성이 희박하여 동물에서 충분한 독성검사를 하기 전에 시행할 수 있다. 초기 선도물질(lead compound)로 부터 개발된 신약 후보가 여럿 있을 때 인체에서 가장 효과가 있을만한 후보를 골라내는 내 유용하다. 가장 가능성이 높은 신약 후보를 충분한 독성검사를 함으 로써 신약 개발의 비용을 절감하며 속도를 높일 수 있 다. 0기 임상시험에 해당하며 미국, 일본에서는 이미 시행을 하고 있고 우리나라 식품의약품안전청도 곧 도입할 예정이다.

\section{$\mathrm{IV}$. 결 론}

분자영상이란 분자생물학(molecular biology), 세포생 물학(cell biology)을 생채영상 (non-invasive in vivo imaging)으로 응용하여 생채 내에서 일어나는 분자 수 준의 변화를 영상화하는 기법으로 분자세포생물학과 첨단영상기술이 발전하여 접목된 새로운 분야이다.

분자영상은 형광(fluorescence), 생물발광(bioluminescence), SPECT, PET, MRI, Ultrasound 등의 영상 기법들을 이 용하여 유전자 치료 모니터링, 세포추적(Cell trafficking), 세포 치료 모니터링, 항체영상, 약제 개발, 분자 상호작용 영상 (Molecular Interaction Imaging), 근 적외선 형광 물질(Near-infrared fluorescent dye)을 이용 한 암 형광 영상, Bacteria 를 이용한 종양 표적 영상 (Imaging active tumor targeting by Light-emitting bacteria), 치료효과 조기 평가, 치료 효과 예측 등에 적용되고 있다.

분자 영상의 미래는 분자세포 생물학, 유전학, 화 학, 약학, 물리학, 전산학, 의공학, 핵의학, 영상의학, 임 상의학 등 여러 학문 분야가 융합되어 상호협조와 공 동연구를 통하여 발전해 나갈 것이다. 분자영상의 태 동으로 미래의 의료의 모습은 질병의 조기진단과 개 인 맞춤형 치료가 가능하게 될 것이다. 


\section{감사의 글}

"이 논문은 2013년도 남부대학교 학술연구비의 지원을 받아 연구되었음"

"This study was supported(in part) by research funds from Nambu University, 2014"

\section{참고문헌}

[1] Daesung Pack, Guirack Choi, Byungsung Han, Byungju Ahn, "Feature values of DWT using MR general imaging and molecular imaging", Journal of the Korean Society of Radiology, Vol. 6, No. 5, pp. 409-414, 2012.

[2] K. Choi, et al., "Molecular Imaging", Vol. 6, pp. 75-84, 2007.

[3] P. Agrawal, G.J. Strijkers, and K. Nicolay, "Adv. Drug Deliv. Rev.", Vol. 62 pp. 42-58, 2010.

[4] Weissleder R, Mahmood U. "Molecular imaging. Radiology", Vol. 219, pp. 316 - 333, 2001

[5] June Key Chung, "General Perspectives for Molecular Nuclear Imaging", Vol. 38, No. 2, pp. 111-114, 2004

[6] http://www.frost.com, "Medical Imaging Markets: Molecular Imaging", Sep. 2012.

[7] Massoud TF., Gambhir SS, "Molecular imaging in Living subjects seeing fundamental biological processes in a new light", Genes Dev., Vol. 17, pp. 545-580, 2003.

[8] Weissleder R. "A clearer vision for in vivo imaging", Nat. Biotechnol., Vol. 19, pp. 316 317, 2001.

[9] Massoud TF, Gambhir SS. "Molecular imaging in living subjects :seeing fundamental biological processes in a new light". Genes Dev., No. 17, pp. 545-580, 2003.

[10] Shah K, Tang Y, Breakefield X, Weissleder R. "Real-time imaging of TRAIL-induced apoptosis of glioma tumors in vivo", Oncogene. No. 22, pp. 6865-6872, 2003.

[11] Kim DE, Ishii K, Shah K, Weissleder R, "Schellingerhout D. Imaging of stem cell recruitment to ischemic infarcts in a murine model", Stroke 2004(In press)

[12] Shah K, Bureau E, Tang Y, Kim DE, Weissleder R, Breakefield X. "Induction of apoptosis in glioma cells by novel TRAILsecreting neural precursor cells (NPC) and in vivo tracking of NPC migration and tumor apoptosis", 33rd annual meeting of society for neuroscience. USA : New Orleans, 2003(Abstract).

[13] Greer LF 3rd, Szalay AA. "Imaging of light emission from the expression of luciferases in living cells and organisms : a review", Luminescence, No. 17, pp. 43-74, 2002.

[14] Jaekyu Roh, Dongeog Kim, "Optical Imaging in the Field of Molecular Imaging", Korean Medical Association, Vol. 47, No. 2, pp. 127-132, 2004.

[15] Luker G.D., Luker K.E., Shama V., Pica C.M., Dahlheimer J.L., Piwnica Worms D., et al., "In vitro and in vivo characterization of a dual function green fluorescent protein - HSV1 - thymidine kinase reporter gene driven by the human elongation factor 1 alpha promoter" Mol. Imaging, No. 1, pp. 65-73, 2002.

[16] Ntziachristos V., Tung C.H., Bremer C., Weissleder R., "Fluorescence molecular tomography resolves protease activity in vivo". Nat Med., No. 8, pp. 757-760, 2002.

[17] Ntziachristos V., Chance B., "Probing physiology and molecular function using optical imaging : applications to breast cancer", Breast Cancer Res., No. 3, pp. 41-46, 2001.

[18] Tung C.H., Mahmood U., Bredow S., Weissleder R., "In vivo imaging of proteolytic enzyme activity using a novel molecular reporter", Cancer Res., Vol. 60, pp. 4953-4958, 2000.

[19] Bremer C., Tung C.H., Weissleder R., "In vivo molecular target assessment of matrix metalloproteinase inhibition", Nat Med., Vol. 7, pp. 743-748,2001

[20] Kircher M.F., Mahmood U., King R.S., Weissleder R., Josephson L., "A multimodal nanoparticle for preoperative magnetic resonance imaging and intraoperative optical brain tumor delineation", Cancer Res., Vol. 63, pp. 8122-8125, 2003.

[21] Weissleder R., Pittet M.J., "Imaging in the era of molecular Oncology", Nature, No. 452, pp. 580 589, 200.,

[22] Day S.E., Kettunen M.I., Gallagher F.A., Hu D.E., Lerche M., Wolber J., Golman K., Ardenkjaer-Larsen J.H., Brindle K.M., "Detecting Tumor response to treatment using huperpolarization 13C magnetic response imaging and spectroscopy", Nat. Med., Vol. 13, pp. 1382 1387, 2007.

[23] T. Ay, X. Havaux, G. Van Camp, B. Campanelli, G. Gisellu, A. Pasquet, J.F. Denef, J.A. Melin and J.L. Vanoverschelde, "Destruction of contrast microbubbles by ultrasound: effects on myocardial function, coronary perfusion pressure, and microvascular integrity", Circulation, Vol, 104, pp. 461-466, 2001.

[24] R. Gramiak and P.M Shah, "Echocardiography of the aortic root", Invest. Radiol., Vol. 3. pp. 356-366, 1986.

[25] Crum L. A., and Fowlkes J. B., "Acoustic Cavitation Generated by Microsecond Pluses of Ultrasound", Nature, Vol. 391, pp. 52 54, 1986. 
[26] Forsberg, F., Shi, W. T., and Goldberg, B. B., "Subharmonic imaging of Contrast Agents", Ultrasonics, Vol. 38, pp. 93 98, 2000.

[27] Franscesca Cavalieri, Meifavh Zhou, Muthupandian Ashokkumar, "The Design of Multifunctional Microbubbles for Ultrasound Image-Guided Cancer Therapy", Current Topic in Medicinal Chemistry, 2010.

[28] Natalya Rapoport, Zhonggao Gao, Anne Kennedy, "Multifunctional Nanoparticles for Combining Ultrasonic Tumor Imaging and Targeted Chemotherapy", J Natl. Cancer Inst., Vol 114, pp. 89 99, 2007.

[29] Kilbanov A. L. "Targeted delivery of gas-filled microspheres. contrast agents for ultrasound imaging", Adv. Drug Deliv. Rev., Vol. 37. pp. 139 157, 1999.

[30] Wu J.C., Tseng J.R., Gambhir S.S., "Molecular imaging of cardiovascular gene products", J Nucl Cardiol. Vol. 11, pp. 491-505, 2004. 